\title{
CULTURAL TRADITION AND SOCIAL CHANGE IN AGRICULTURE
}

\author{
HANS PONGRATZ*
}

\section{TRADITIONAL PEASANT CULTURE AS A SUBJECT OF RURAL SOCIOLOGY'}

The development of agriculture in the past decades has been determined worldwide by modernization measures. Mechanization and intensification of production, rationalization of farm management and adaptation to urban-industrial lifestyles were the goals of modernization which were also pursued by the various disciplines of agricultural science. In so far as any attention at all was paid to farm people's culture, i.e. the totality of ways of life and rules of behaviour among the farming population (which must be differentiated according to region), it was usually regarded as outmoded and the remnant of a tradition which exerted a disruptive influence on the modernization process. It was rural sociology in particular which set itself the goal of overcoming and excluding such 'backward' cultural manifestations.

In recent years, however, analyses in the field of research into developing countries and cultural-anthropological studies have cast a new light on the significance of farming culture ${ }^{2}$. They reveal that in their internal structures and processes, traditional regional cultures have usually successfully adapted to the needs of people and the demands of the environment. From this perspective, modernization measures may even appear as a retrograde step:

In the majority of cases where development aid contributed to noticeable changes, we observed the introduction of less flexible arrangements, which probably reduce parameters of security (Elwert \& Bierschenk 1988: 110).

Even in a developed western industrialized nation such as West Germany, a traditional peasant culture has been preserved in a variety of forms and with different results. In interviews with women living and working on smallholdings Inhetveen and Blasche discovered to their surprise "the extent to which traditional orientations and behaviour have remained alive and effective" (1983:231). They came across attitudes of identification with the farm, orientations towards subsistence agriculture and a

${ }^{\text {3ै }}$ Universität der Bundeswehr München, Fakultät für Pädagogik, Neubiberg, FRG 
traditional work ethic. Bohler and Hildenbrand (in this issue) demonstrate with various case studies how modern and traditional modes of behaviour among farming families in varying combinations are reconciled with each other. The cultural-anthropological monograph of a village by Brüggemann and Riehle (1985) follows the theory that traditional elements of farming culture have not remained confined to families engaged in agriculture, but are firmly anchored in large sections of the rural population. This was valid for various peasant attitudes, such as the 'omnipresence of work', the regularity of their perception of time, the orientation towards farm and property, or their mistrust of external influence. Rural behavioural patterns such as these can remain astonishingly stable, even when people are employed in modern industrial firms (Brock \& Vetter 1986).

With these findings as my point of departure, it is my intention in this paper to reconsider the relationship between cultural traditions and the modernization process in agriculture ${ }^{3}$. These theoretical considerations are, in my opinion, relevant for the further development of analytical explanatory paradigms in rural sociology, as well as other aspects. In view of the symptoms of an impending social, economic and ecological crisis in modern agriculture, I wish to offer here a contribution to the sociopolitical discussion on the future of agriculture. Up to the present, the course of agricultural development has been regarded in an increasingly critical manner by theoverwhelming majority of West Germans, according to the results of an opinion poll carried out in $1987^{4}$. Research into the causes and the search for solutions will therefore become more important in public debate on this problem. In the following sections various interpretations of empirical findings are presented. An attempt is made to extrapolate some general theoretical considerations from these and finally, possible social consequences are discussed in detail.

\section{ADAPTATION STRATEGIES OF FARMING IN INDUSTRIAL SOCIETY}

As early as the 1950 s, different interpretations of the process of integrating the rural population into industrial society were the subject of heated discussion among West German rural sociologists. Various exploratory monographs on the subject of villages had shown clear evidence of the adaptation of the rural population to urban-industrial change. Kötter, adhering to the modernization theory, considered this proof "that the differences between urban and rural communities had become blurred to a large extent" (1956: 23) and that the farming community had lost its autonomous basis of values and norms. Weippert opposed his theory of the 'self-assertion of peasant life in new form' to this theory of the 'homogenization of urban and rural areas'. He interpreted the adaptation process undergone by the rural population as a "new historical type" 
(Weippert 1956: 201) of farming community which in the actual process of change had demonstrated its capacity to survive in its essential form. The third theory of a 'limited autonomy in the process of adaptation' characterizes Wurzbacher's interpretation. This theory pointed out the socially integrating and stabilizing effect of this specific "rural synthesis between individual freedom and social obligation, and between progressive and conservative elements" (Wurzbacher \& Pflaum 1954: 290). With the triumph of the modernization-theoretical paradigm in rural sociology at the end of the 1950s, these stimulating discussions ontheory came to a premature end. The goal of "correcting beliefs" (Kötter 1958: 173), the disintegration of traditional rural moral values and norms of behaviour were to determine from now on the tenor of research in West German rural sociology.

In its investigations into the state of rural adaptation, empirical research was forced to confirm the continuation of traditional attitudes and behaviour in the rural population. This continuation of rural culture was not conspicuous in commercial behaviour because it was here that the collision with the modernization goals of capitalist entrepreneurs was most obvious. Thus for the 1960 s van Deenen established that

many farm managers are not able to make use of the possibilities offered by technological and economic progress to increase production on a basis similar to that of industry, or even to recognize the chances provided by modern 'agribusiness' (1970: 4).

Judgements such as these, claiming backwardness and lack of ability to adapt, are in contradiction to the extensive mechanization and diverse rationalization measures which were actually carried out by farmers at that time ${ }^{5}$. Evidently, many farmers submitted to modern technical and economic demands without fully accepting a corresponding way of thinking related to business management.

As a result, since the beginning of the 1970s, smaller and medium-sized farmers reacted to political and economic pressure by expanding production with corresponding specialization and intensification measures rather than by giving up the farm, which according to the rationale of economics would have been the correct solution. They thus pursued the traditional goal of preserving the farm and attempted to achieve it with the traditional farming work ethic. If land and capital were lacking, then more money was borrowed and more labour capacity was provided by the family. Where necessary, more labour was invested by familymembers in production and building construction, and they not only provided general help, but also undertook work usually done by masons, carpenters and plumbers. 
Nor did the mechanization process conflict with the traditional peasant attitude to farm work. After initial hesitation, they accepted production technology so willingly that farming is now considered to be overmechanized. But however necessary mechanization in general may have been, in individual cases the hard profit factor was often forgotten. The actual cost of machines was not properly calculated. Decision criteria were based on traditional attitudes to buying. They include financial viability (which normally does not mean that a machine pays, but that it can be afforded), reduction of labour (from the perspective of the farmer's labour needs), independence in carrying out work (the 'freedom' which for farmers represents the decisive advantage of their work) and prestige (as many farmers admit). High costs of purchase were partially offset by increased input of farm labour into repair and servicing of the machines. Many farmers developed a great interest in agricultural machinery and became quite expert in keeping it in working order. Mechanization turned them into admirable mechanics, but not into good salesmen.

Evidently the farming community successfully used traditional work and management strategies in the modernization process. Inhetveen and Blasche sum up as follows:

Traditionalism can be considered as one of the most basic reasons why small holdings have managed at all to survive the attacks on their existence that arose from their integration into the capitalist economic system (1983: 232).

On this basis it was possible to fulfil simultaneously the individual goal of preservation of the farm and the societal goal of cheap mass-produced food $^{6}$. Similarcombinations of traditional and modern behaviour can be observed in other areas of farming life, for example in family orientation or socio-political awareness (see Pongratz 1987). They lead to the hypothesis that the rural population has gone its own way in modernization; it has not rejected the demands of modern industrial society, but has by no means surrendered its cultural traditions ${ }^{7}$. Before turning to the social and economic cost of this process and to the possible socio-political consequences, I wish to present some general reflections on the capacity for change in peasant culture.

\section{THEORIES ON THE CAPACITY FOR CHANGE IN TRADITIONAL PEASANT CULTURE}

It was not only the classic theories of modernization, which consider the general dissemination of the model of western industrial society to be the goal of progress, that did not acknowledge peasant culture as being capable of change. Even in newer, more differentiated approaches, the paradigm 'peasant' equals 'traditional' equals 'passive and opposed to 
change' remains implicitly influential. In agreement with Bendix (1966), a model of "partial modernization" in which traditional and modern elements each take on specific cultural connections, is accepted ${ }^{8}$. In this sense, a distinction is made between "the unity of modernity" as the aim of development with an abstract orientation towards rationalization criteria, or system-theoretical standards, and "the many roads of modernization", i.e., the various development processes which are the result of different cultural conditions (see Touraine 1988: 444). Macro-sociological analyses lead to ever more differentiated development typologies and are particularly concerned with the phenomenon of "society in transition" (see Flora 1974: 14ff). The combination of traditional and modern elements and their social dynamics is considered a typical characteristic of this transitional phase and is generally described as a crisis situationwhich must be mastered. Social change, however, as sociological research in the historical comparison of developing countries as well as in modern ethnography reveals, is not confined to the modernization process, or to society in transition. So-called traditional societies also possess their own more or less marked development dynamics: "These societies have specific ways of creating innovations and transforming and incorporating innovations brought from outside" (Elwert \& Bierschenk 1988: 99).

A more exact terminology is helpful in the further theoretical analysis of the connection between peasant culture, traditionality and social change. The terms 'traditional' versus 'modern' (see Bohler \& Hildenbrand in this issue) can be given an exact sociological definition and applied consistently as a theoretical basis in accordance with Weber and Parsons, using characteristic features of an ideal type. However, in accordance with the ideas of Weber (1956) and Mannheim (1964), German sociology has been dominated by a concept of tradition which has mainly taken into account the reactive and passive elements of tradition ${ }^{9}$. Tradition is comprehended as a rigid and vague retention of old customs. Rural sociology further devalued peasant traditionality by linking it with Fascist-influenced peasant ideology (see Ziche 1970).

The terms can, however, also be used as relational concepts which express differing temporal continuity (Bausinger 1985: 186) and it is in this sense that I am using them. Independent of its content, traditionality finds expression in a certain continuity with the past, whereas modernity describes phenomena which are comparatively new in historical terms. In this case it is important to observe more exactly cultures participating in the social process and their historical peculiarities, such as a peasant culture and a capitalist-industrial culture, and to characterize them in their specific relationships, for example, as marginal or dominant cultures. Leaving aside terminological dichotomy, I shall now outline in more detail the social dynamics of the relationship between traditional peasant 
and modern urban-industrial culture with reference to four theories (see Inhetveen \& Blasche 1983).

(1) The clash with ruling cultures and the control of external influences have marked peasant culture for generations. As part of popular culture it was never closed to the outside, "but should be regarded as in a state of flux and continual conflict with the pressures exerted by an elitist culture" (Bausinger 1985: 184). The modernization process seen from this historical perspective is 'simply' a new phase with new claims to dominance. Experience and rules for mastering change have become a permanent feature of rural culture (Brüggemann \& Riehle 1985: 133ff). It is because they have proved their value during constant change that they contribute to its stability and continuity. In confrontation with industrial culture, however, limited ability of peasant culture to control change in social structure become evident.

(2) Individual control of modernization demands and its integration into everyday life is achieved not in opposition to traditional rules of behaviour, but is conveyed through it ${ }^{10}$. Traditional behaviour, therefore, does not imply a rigid and passive clinging to old customs. Instead on the basis of transmitted rules, it continually demands new interpretations of a changed reality which has to be actively put into practice in everyday life. In so far as these demands come from the ruling culture and confront peasant culture in a heteronomous fashion, then peasant culture reacts mainly with defensive strategies in its implicit awareness of unequal power relationships ${ }^{11}$. It is this defensive attitude which is frequently interpreted by modernization theorists as mere passivity.

(3) The stability of traditional peasant culture is essentially determined by structural factors. Its successful self-assertion in social change is dependent on the maintenance of corresponding social and economic structures. With the organizational form of the farm based on management by the family and the specific conditions of living in rural areas, structures of small-scale farming in West Germany have been preserved to a remarkable degree. They guarantee a certain "constancy of areas of experience" (Bausinger 1985:187) as well as making possible and demanding a continuation of traditional behaviour. The tension between peasant and urban-industrial culture rests on this structured contradiction between rural family farm and capitalistindustrial economic and social system. Social dissatisfaction, agrarian political protest, stress symptoms and mental illness in the farming community can be interpreted as expression of their inclusion in alien and in part contradictory social structures.

(4) The consequences of this interchange between peasant and urbanindustrial culture are ambivalent for both parties. The defensive 
reaction to modernization demands makes possible a modified maintenance of the desired way of life including improved living conditions for farming families. Aggravated structural contradictions can lead to heavy pressures and in the long term to giving up agriculture as a means of earning a livelihood. On the other hand, proponents of modernization in agriculture are of the opinion that they are slowly but surely achieving their goal. With the mechanization and intensification of production, crucial modernization goals are attained, relying also on traditional work and economic strategies ${ }^{12}$. At the same time, undesirable peasant strategies have stabilized in this process and remain a continuing potential source of resistance. They hinder the planned expansion of the modernization process which can only be achieved at great cost.

The example of the sociologically well-documented development of the farm family (see Rosenbaum 1982: 47ff) demonstrates how easily the capacity for change in peasant culture is underestimated if one only considers the present contrast with urban-industrial culture. Sociological research shows that the modernization model of the bourgeois family, starting from "several types of family distinctly differing from each other" (ibid: 476) at the end of the eighteenth century has to a large degree become the social reality of the present. For different types of family this change meant radically different kinds of transformation. Bourgeois and proletarian families, as "prototypes of the "modern family"' (ibid), had a comparatively short process of modification to go through. The peasant family, in contrast, which differed from the bourgeois family to a much greater extent two hundred years ago than it does today, has evidently had to pass through a particularly long process of modernization. As a result of this, the paradoxical situation arises that the farm family, which is still considered backward, has experienced and mastered more change than any other group.

\section{THE CRISIS OF AGRICULTURE AND THE CHANCE OF SELF-RELIANT DEVELOPMENT}

Analyses of the crisis in West German agriculture show that the costs of this development are increasing both for farming families and for society in general. Increasing subsidies, over-production and environmental damage as a result of modern agricultural methods have frequently been described (e.g. Priebe 1985). At the same time, in spite of various technological, demographic and economic adaptation processes, economic pressure continues to be exerted on agricultural production units, and this increases the socio-economic differences between them (see Bergmann in this issue). There are indications of a split in agriculture in which only a 
proportion of farms using intensive methods of production are able to earn a livelihood (often at the expense of the environment) while a growing number of smallholdings and medium-sized farms are forced into part-time farming or giving up agriculture entirely as a means of making a living. Many farming families who during the 1970 s tried to save the farm by investing even more labour and money in it, now find themselves in a fundamental identity crisis in view of future prospects. In spite of ever-increasing pressure, working on the farm no longer makes any sense as regards the value of products or the aim of preserving the farm. Consequent psychological symptoms in farming families have been described in various studies (Breuer \& Scheer 1988; Meyer-Mansour 1988; Hildenbrand 1988).

If, however, peasant tradition can only be preserved at the cost of ever-increasing pressures, the question arises whether a self-reliant 'modernization path' for agriculture can be justified. Will the modernization theorists with their demands for comprehensive adaptation prove to be right in the long run? A glance at the most extensively modernized agricultural systems shows that rigorous economic rationalization creates just as many problems. Both capitalist entrepreneurial agriculture in the USA and collective, partially state-controlled socialist agriculture in the USSR are in severe difficulties.

Since the beginning of the 1980s, agriculture in the USA has been going through one of the worst crises in its history, which is evident in that many farmers are hopelessly in debt. Since large sums were invested in agricultural production according to capitalist management methods in the 1970s, it could be assumed that the crisis was the result of replacing the more cautious peasant-minded farmers by their more progress-oriented colleagues. Rural sociological surveys carried out in various states in the US all agree that the farmers most affected are those younger ones who entered agriculture after 1970 . They are for the most part better trained and more inclined to use modern management techniques and make better use ofproduction possibilities. "Their characteristics are, in fact, those normally associated with innovative and adaptive producers" as Murdock et al. (1986: 426) concluded. The relative success ${ }^{13}$ of more peasantoriented farms stands in direct inversion to the failure of progressive entrepreneurs in capitalist agriculture:

Those who best stand to survive the economic disruptions of the 1980 s are persons who, because of choice or necessity, were conservative in their past farming investments and adoption of new capital-intensive technologies. Ironically, oncemaligned and seemingly dysfunctional orientations have proved, in light of recent developments, to have been perhaps the more judicious response of family farmers to social and economic change (Bultena et al. 1986: 447). 
Since the beginning of the 1970s, agriculture in the USSR has experienced continuous difficulties (see Bergmann 1988 and Shanin 1989). In spite of increased deployment of modern means of production, the harvests stagnated and environmental damage increased. In the USSR too the considerable significance of social factors in this crisis is evident. Too much bureaucracy and centralization, few opportunities to partake in the decision-making process in the collectives and bad rural living conditions have deprived agricultural producers of any motivation. In order to solve the crisis in the USSR, demands are being made by protagonists of perestroika, such as Gorbachev and Zaslavskaya, not only to increase economic incentives but also to undertake structural changes in order to revive old peasant farming methods. A new sense of responsibility towards nature and society, which is based on peasant structures and behaviour patterns, appears necessary for the increase of agricultural production.

It needs the farmer's confidence that he and his family will be able to farm the same land in the future and to continue living in the same place, to underpin his efforts (Shanin 1989: 15).

Both modernization roads in agriculture, unconditional capitalization as well as socially destructive collectivization, appear to be breaking down from a social, ecological and also economic aspect. At the same time, in the analyses of both agricultural systems, reference is made to the significance of peasant structure and behaviour for overcoming the crisis. Comparing these findings with West German experiences makes it reasonable to presume that it is not the combination of elements of modern urbanindustrial and traditional peasant cultures per se which is responsible for the crisis in this country, but rather that the essential social structuring has not succeeded. Evidently, the specific interaction between efforts to modernize and coping with them in the farming community of West Germany (and presumably in many other parts of Europe) reveals destructive dynamics exerting intense pressure. This interaction is based on mutual misjudgements and structural contradictions which, from the standpoint of all participants, leads to a series of undesired consequences.

It seems to me that the factors determining these conditions are, firstly, that the model of the agricultural entrepreneur, which is propagated by scientists and politicians, farmers' unions and agribusiness alike, is not appropriate for the structure of family farms and their socio-economic integration in West Germany (see Bergmann in this issue). It neglects the perspective on the household and excludes the dependence of agricultural producers on branches of the economy associated with them. Family business shows specific conditions of production, e.g. use of labour, cost structure of the farm unit, management and direction of the household, to which the commercial management model does not do justice. 
Secondly, important chances for integrating rural-farming and urbanindustrial behavioural demands have been missed. It must be pointed out in particular that the possibilities of education and training and cooperation for self-reliant development of agriculture have been underestimated. Independent realization of development potential demands corresponding information in agricultural training as well as further education. Both the training system and the attitudes of farmers to education hardly take account ofthese possibilities. Traditional farming knowledge, which could fulfil important functions of integration and identification in the education process, remains more or less excluded. The various means of co-operation (from machine rings to grouping of farms) for the purposes of reducing the workload and improving individual economic situations, are barely used because they do not appear to fit into either the entrepreneurial or the traditional picture of the farmer.

Finally, there is a marked difference in the exercise of power between the institutions that drive the modernization process forward and the farming community. In a variety of ways this power became a political object of interest to large landowners, industrial capital and state bodies. Thereby the farming community became enmeshed in a specific network of linked economic, political and socio-cultural relationships to the industrial-capitalist area of society (see Pongratz 1987). Farm people in this situation try to preserve elements of their own way of life and take on a defensive attitude. As a result, they have achieved a particular type of development in agriculture, but not one which has been self-reliant.

If a self-reliant development for agriculture is sought for the future, then inequalities in the power structure must be demolished and political goals and measures must be oriented towards the existing, regionally varied structural and cultural living conditions of the farming community. However, inherent in the efforts directed at the social and political emancipation of the farming population is the danger that they might prove effective as control strategies or be perceived as such. From the social institutions involved, therefore, is required above all a readiness to allow the farming community to participate in decisions about the shape and extent of change it undergoes, according to its own criteria of relevance and on the basis of proven norms of behaviour. This presupposes confidence in the capacity for change and readiness to integrate on the part of the farming community. But it also requires restricting the demands for modernization on the part of different scientific and political agrarian institutions. Thus the fundamental question arises, as to how far in a modern society subject to rapid change, autonomous and self-reliant forms of development are possible and desirable. Not only should the growing crisis associated with the modern path of development encourage it, but also confidence in social groups such as the farming community. Its previous reaction to social change does not give rise to any anxiety that it 


\section{would endeavour to take retrograde steps which would lead to disintegration.}

\section{NOTES}

* The paper was translated by M. Kinsella.

1. The English term 'peasant' is an inadequate translation of the German words 'Bauer' and 'bäuerlich'. 'Bäuerlich' refers to small-scale and medium-sized family farms more generally and describes major parts of West German agriculture in the present, too. Because of this difference I will use the term 'peasant' sparingly and only with regard to traditional elements of culture in the farming community.

2. See articles in issues no. 1 (1984) and no. 2/3 (1988) of Sociologia Ruralis.

3. The hypotheses in this article were mainly developed in Pongratz (1987) and Pongratz (forthcoming).

4. In the opinion poll carried out by the EMNID Institute on the "Image of German Agriculture 1987" $92 \%$ tended to the opinion that agriculture used too many fertilizers and pesticides. $85 \%$ of those interviewed preferred a majority of small family farms to a smaller number of industrialized production units.

5. This contradiction was also noticed by Ziche: "In reality the farmers are acting faithfully in accordance with the demands of industrial society, the rapid structural change in agriculture is proof of this." However, he does not see any reason to re-evaluate his judgement of backwardness: "But on an intellectual level they appear to cling to a pre-industrial mind-set" (1970: 24$)$.

6. It is also becoming increasingly evident that traditional farm management strategies are to a large degree environmentally friendly.

7. Whereby retrospectively the theory of 'limited autonomy' proposed by Wurzbacher \& Pflaum (1954) appears to be confirmed.

8. A detailed critique of classical modernization theory and an account of its further development is to be found in Eisenstadt 1979 (especially p. $128 \mathrm{ff}$ ).

9. It becomes the very epitome of social inertia in the widespread combination of two concepts which were certainly considered separately by Weber, i.e., that of traditional action (Weber 1956: 12) being action as a result of traditional custom, and that of traditional authority (ibid: 130ff), the legitimacy of which is based on the sanctity of the ancient order.

10. Compare also the terms 'cultural sifting' and 'bilateral orientation' and their application to peripheral European regional development areas in Reimann (1986).

11. Spittler (1989) in particular pointed out 'defensive strategies' in rural communities.

12. The functionality of traditional thought and behaviour patterns for modernization processes was also confirmed in research on developing countries (e.g. Hoselitz 1961) and in ethnology (e.g. Pitt 1976).

13. The success of traditionally oriented farm units must be qualified in two respects. On the one hand, their income is very low and many of them will be forced in the long term to find an additional source of earnings. On the other hand, the main beneficiaries of the crisis are commercial companies who have made healthy profits from their investment in agriculture, but at the cost of ecological damage, the extent of which is difficult to estimate as yet.

\section{REFERENCES}

BAusinger, H. (1985), Traditionale Welten. Kontinuität und Wandel in der Volkskultur, Zeitschrift für Volkskunde, 81, 173-191 
BENDIX, R. (1966), Tradition and modernity reconsidered, Comparative Studies in Society and History, 9, 292-346

Bergmann, TH. (1988), Kommunistische Agrarsysteme, Sozialismus, 2-88, 43-51

Breuer, M. \& G. Scheer (1988), Psychosoziales aus der Provinz, in Agrarsoziale Gesellschaft, Hg., Ländliche Gesellschaft im Umbruch (Göttingen: Agrarsoziale Gesellschaft), 210-239

Brock, D. \& H.-R. VetTer (1986), Technische Dynamik und soziale Beharrung, Soziale Welt, 37, 208-236

Brúggemann, B. \& R. Riehte (1986), Das Dorf. Über die Modernisierung einer Idylle (Frankfurt/Main \& New York: Campus)

Bultena, G., P. LAsley \& J. Geller (1986), The farm crisis: patterns and impacts of financial distress among Iowa farm families, Rural Sociology, 51, 436-448

DEENEN, B. VAN (1970), Wie beurteilen landwirtschaftliche Betriebsleiter ihre berufliche und gesellschaftliche Position. Ergebnisse empirischer Forschungsarbeiten, Berichte über Landwirtschaft, 48, 1-11

EISENSTADT, S. N. (1979), Tradition, Wandel und Modernität (Frankfurt/Main: Suhrkamp)

ELWERT, G. \& T. BiersCHENK (1988), Development aid as an intervention in dynamic systems. An introduction, Sociologia Ruralis, 28, 99-112

FLORA, P. (1974), Modernisierungsforschung. Zur empirischen Analyse der gesellschaftlichen Entwicklung (Opladen: Westdeutscher Verlag)

HILDENBRAND, B. (1988), Modernisierungsprozesse in der Landwirtschaft und ihre Bewältigung. Vergleich einer 'schizophrenen' und einer 'normalen' Familie, in K. LüsCHER et al, Hg., Die 'postmoderne' Familie (Konstanz: Universitätsverlag), 297-311

Hoselrtz, B. F. (1961), Tradition and economic growth, in R. BraIBANTI \& J. J. SPENGLeR, eds., Tradition, values and socio-economic development (Durham: Duke University Press), 83-113

InHETVEen, H. \& M. Blasche (1983), Frauen in der kleinbäuerlichen Landwirtschaft (Opladen: Westdeutscher Verlag)

KöLsch, O. (1989), Die Lebensform Landwirtschaft in der Modernisierung. Grundlagentheoretische Betrachtungen und empirische Deutungen zur Agrarkrise aus der Lebenswirklichkeit von konventionell und ökologisch wirtschaftenden Landwirten aus Niedersachsen, Dissertation (Göttingen: Georg-August-Universität)

Kötrer, H. (1956), Die Gemeinde in der ländlichen Soziologie, in R. KÖNIG, Hg., Soziologie der Gemeinde (Opladen: Westdeutscher Verlag), 12-25

KötTER, H. (1958), Landbevölkerung im sozialen Wandel (Düsseldorf \& Köln: Diederichs)

MANNHEIM, K. (1964), Wissenssoziologie. Hg. von K. H. Wolff (Neuwied am Rhein \& Berlin: Luchterhand), 408-508

MeYer-Mansour, D. (1988), Agrarsozialer Wandel und bäuerliche Lebensverhältnisse, in Agrarsoziale Gesellschaft, Hg., Ländliche Gesellschaft im Umbruch (Göttingen: Agrarsoziale Gesellschaft), 240-260

MURDOCK, S. H. et al. (1986), The farm crisis in the Great Plains: implications for theory and policy development, Rural Sociology, 51, 406-435

PrTt, D. C. (1976), Development from below, in Ibid., ed., Development from below. Anthropologists and Development Situations (The Hague \& Paris: Mouton), 7-19

Pongratz, H. (1987), Bauern - am Rande der Gesellschaft? Eine theoretische und empirische Analyse zum gesellschaftlichen Bewußtsein von Bauern, Soziale Welt, 38, 522-544

Pongratz, H. (forthcoming), Ländliche Lebenswelt und agrarpolitische Krise in ihren Auswirkungen auf das gesellschaftlich-politische Bewußtsein von Bauern, in B. Claussen \& R. Geissler, Hg., Politisierung des Menschen. Instanzen der politischen Sozialisation (Weinheim: Deutscher Studienverlag)

PRIEBE, H. (1985), Die subventionierte Unvernunft. Landwirtschaft und Naturhaushalt (Berlin: Siedler) 
ReimanN, H. (1986), Die Vitalität 'autochthoner' Kulturmuster. Zum Verhältnis von Traditionalität und Moderne, in F. NEIDHARDT et al, Hg., Kultur und Gesellschaft (Opladen: Westdeutscher Verlag), 358-378

Rosenbaum, H. (1982), Formen der Familie. Untersuchungen zum Zusammenhang von Familienverhältnissen, Sozialstruktur und sozialem Wandel in der deutschen Gesellschaft des 19. Jabrhunderts, (Frankfurt/Main: Suhrkamp)

Salamon, S. \& K. Davis-Brown (1986), Middle-range farmers persisting through the agricultural crisis, Rural Sociology, 51, 503-512

SHANIN, T. (1989), Soviet agriculture and Perestroika: four models. The most urgent task and the furthest shore, Sociologia Ruralis, 29 (1), 7-22

SPITTLER, G. (1980), Abstraktes Wissen als Herrschaftsbasis. Zur Entstehungsgeschichte bürokratischer Herrschaft im Bauernstaat Preussen, Kölner Zeitscbrift für Soziologie und Sozialpsychologie, 32, 574-604

TOURAINE, A. (1988), Modernity and cultural specifities, International Social Science Journal, 40, 443-457

WEBER, M. (1956), Wirtschaft und Gesellschaft. 4. Auflage (Tübingen: Mohr)

Weippert, G. (1956), Grundfragen der ländlichen Soziologie, in H.-J. Seraphim, Hg., Deutsche Siedlungs- und Wohnungspolitik (Köln-Braunsfeld: Verlagsgesellschaft Rudolf Müller), 187-229

Wurzbacher, G. \& R. Pflaum (1954), Das Dorf im Spannungsfeld industrieller Entwicklung (Stuttgart: Enke)

ZICHE, J. (1970), Das gesellschaftliche Selbstbild der landwirtschaftlichen Bevölkerung in Bayern (München: Bayerisches Landwirtschaftliches Jahrbuch) 